\title{
Microcephaly-deafness-intellectual disability syndrome
}

INSERM

\section{Source}

INSERM. (1999). Orphanet: an online rare disease and orphan drug data base.

Microcephaly-deafness-intellectual disability syndrome. ORPHA:2533

Microcephaly-deafness-intellectual disability syndrome is characterised by microcephaly, deafness, intellectual deficit and facial dysmorphism (facial asymmetry, prominent glabella, low-set and cup-shaped ears, protruding lower lip, micrognathia). It has been described in a mother and her son. The mode of inheritance is probably autosomal dominant. 